\title{
Pathogen communities of songbird-derived ticks in Europe's low countries
}

\author{
Dieter Heylen ${ }^{1 *}$, Manoj Fonville², Arieke Docters van Leeuwen ${ }^{2}$, Arjan Stroo $^{3}$, Martin Duisterwinkel $^{4}$, \\ Sip van Wieren ${ }^{5}$, Maria Diuk-Wasser ${ }^{6}$, Arnout de Bruin ${ }^{2}$ and Hein Sprong ${ }^{2}$
}

\begin{abstract}
Background: Birds play a major role in the maintenance of enzootic cycles of pathogens transmitted by ticks. Due to their mobility, they affect the spatial distribution and abundance of both ticks and pathogens. In the present study, we aim to identify members of a pathogen community [Borrelia burgdorferi (s.l.), B. miyamotoi, 'Ca. Neoehrlichia mikurensis', Anaplasma phagocytophilum and Rickettsia helvetica] in songbird-derived ticks from 11 locations in the Netherlands and Belgium (2012-2014).

Results: Overall, 375 infested songbird individuals were captured, belonging to 35 species. Thrushes (Turdus iliacus, T. merula and T. philomelos) were trapped most often and had the highest mean infestation intensity for both /xodes ricinus and I. frontalis. Of the 671 bird-derived ticks, 51\% contained DNA of at least one pathogenic agent and 13\% showed co-infections with two or more pathogens. Borrelia burgdorferi (s.l.) DNA was found in 34\% of the ticks of which majority belong to so-called avian Borrelia species (distribution in Borrelia-infected ticks: 47\% B. garinii, 34\% B. valaisiana, 3\% B. turdi), but also the mammal-associated B. afzelii (16\%) was detected. The occurrence of B. miyamotoi was low (1\%). Prevalence of R. helvetica in ticks was high (22\%), while A. phagocytophilum and 'Ca. N. mikurensis' prevalences were $5 \%$ and $4 \%$, respectively. The occurrence of B. burgdorferi (s.l.) was positively correlated with the occurrence of ' $\mathrm{C}$. N. mikurensis', reflecting variation in susceptibility among birds and/or suggesting transmission facilitation due to interactions between pathogens.
\end{abstract}

Conclusions: Our findings highlight the contribution of European songbirds to co-infections in tick individuals and consequently to the exposure of humans to multiple pathogens during a tick bite. Although poorly studied, exposure to and possibly also infection with multiple tick-borne pathogens in humans seems to be the rule rather than the exception.

Keywords: Co-infection, Bird, Ixodes ricinus, Borrelia burgdorferi (s.l.), Borrelia miyamotoi, Rickettsiales

\section{Background}

Songbirds are swift transporters of ticks and tick-borne pathogens, spreading them over long distances on bird migration and dispersal routes. They are important pathogen reservoirs and carriers of infected ticks in areas that are less accessible to mammals, but still frequently visited by humans, such as islands, green space and gardens in urbanized areas [1-5]. Not only their contribution in the terrestrial cycles of pathogens has become clear during the past decades, but also their

\footnotetext{
* Correspondence: dieter.heylen@uantwerpen.be

${ }^{1}$ Evolutionary Ecology Group, University of Antwerp, Antwerp, Belgium

Full list of author information is available at the end of the article
}

importance in maintaining tick populations is now generally recognized [6-9].

In Europe, bird-associated Borrelia burgdorferi (s.l.) species such as B. garinii and B. valaisiana [10-14] have been associated with human Lyme borreliosis $[15,16]$. However, limited information is available on the birds' contribution to the cycles of other human tick-borne pathogenic agents, as well as the mechanisms of cooccurrence of more than one pathogenic agent in individual birds and bird-derived ticks ("co-infection") [17]. Understanding the mechanisms underlying co-infections in ticks is important, as co-infections in hosts in which tick bites are relatively low (e.g. humans) can result from the attachment of a single co-infected tick rather than sequential bites of multiple singly-infected ticks [18]. 
Simultaneous infections of multiple pathogen species can lead to increased pathogenicity, can affect pathogen proliferation dynamics in the hosts, can influence the host's immune responses, can affect the distribution of pathogens in the host body and can complicate the diagnosis and treatment of disease [19-23].

Here, we investigated the (co-)occurrence of tick-bornepathogens of humans and domesticated animals, for which songbirds are believed to potentially contribute to their maintenance, either as transmission facilitator (i.e. via local or systemic infections) or as vehicles of infected ticks. The pathogens considered are B. burgdorferi (s.l.) [4, 24], Anaplasma phagocytophilum [24-27], 'Candidatus Neoehrlichia mikurensis' [28, 29], Rickettsia helvetica $[3,17,30,31]$ and Borrelia miyamotoi $[23,29]$. Among the avian B. burgdorferi (s.l.) species, B. garinii is responsible for human neuroborreliosis, while $B$. valaisiana has low pathogenicity, if any at all, for humans $[32,33]$. The epidemiological importance for humans of $B$. turdi is currently unknown. Borrelia miyamotoi is a member of the relapsing fever group of Borrelia spirochaetes and can be hosted by rodents [34]. Rickettsia helvetica belongs to the spotted fever group and is an obligate intracellular bacterium, potentially causing cardiac and neurological problems in humans [35, 36]. Anaplasma phagocytophilum is an obligate intra-cellular rickettsia-like bacterium that can infect neutrophils causing granulocytic anaplasmosis in humans, livestock and companion animals [37]. The rickettsia-like bacterium ' $\mathrm{Ca}$. N. mikurensis' is associated with febrile patients [38] and has been found in tissues of wild rodents $[34,39,40]$.

The scope of our study is to identify the members of the pathogen community in tick species derived from songbird species in Europe's Low Countries (Belgium and the Netherlands), to define their infection prevalence, and to investigate whether the occurrences of different pathogenic agents are independent of each other.

\section{Methods}

\section{Bird trapping and collection of ticks}

From 2012 to 2014, trained and experienced birdbanders opportunistically collected ticks from songbirds that were caught using Japanese mist nets in seven locations in the Netherlands (Eemshaven: $53^{\circ} 26^{\prime} 18.91^{\prime \prime} \mathrm{N}, 6^{\circ}$ 50'7.77"E; Hijkerveld: 51 $52^{\prime} 16.15^{\prime \prime} \mathrm{N}, 4^{\circ} 28^{\prime} 49.84^{\prime \prime} \mathrm{E}$; Schiermonnikoog: 53⒉ $9^{\prime} 21.74^{\prime \prime} \mathrm{N}, 6^{\circ} 13^{\prime} 51.27^{\prime \prime} \mathrm{E}$; Almere Oostvaardersdijk: 52²4' $20.19^{\prime \prime} \mathrm{N}, 5^{\circ} 10^{\prime} 40.45^{\prime \prime} \mathrm{E}$; Ankeveen: $52^{\circ} 15^{\prime} 51.19^{\prime \prime} \mathrm{N}, 5^{\circ} 5^{\prime} 53.71^{\prime \prime} \mathrm{E}$; Nunspeet: $52^{\circ} 23^{\prime}$

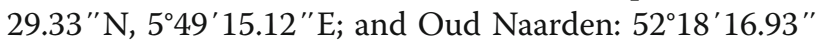
$\mathrm{N}, 5^{\circ} 11^{\prime} 32.29^{\prime \prime} \mathrm{E}$ ) and four in Belgium (Merksplas: $51^{\circ}$ $21^{\prime} 29.48^{\prime \prime} \mathrm{N}, 4^{\circ} 51^{\prime} 48.77^{\prime \prime} \mathrm{E}$; Vorselaar: $51^{\circ} 12^{\prime} 9.08^{\prime \prime} \mathrm{N}, 4^{\circ}$ 46'15.17"E; Wilrijk: 51 $10^{\circ} 5.91^{\prime \prime} \mathrm{N}, 4^{\circ} 23^{\prime} 39.43^{\prime \prime} \mathrm{E}$; and Brecht: $\left.51^{\circ} 20^{\prime} 58.75^{\prime \prime} \mathrm{N}, 4^{\circ} 38^{\prime} 15.80^{\prime \prime} \mathrm{E}\right)$. No information was obtained on the number of birds without ticks.
Songbirds could be classified in nine categories following their foraging habitats (see Table 1) based on the information provided in a reference work [41] and the expert knowledge of two experienced bird-watchers of the University of Antwerp (J. Elst and D. Heylen). Immediately after collection, the ticks of an individual bird were immersed in a single tube filled with ethanol (80\%), which was subsequently stored at $-20{ }^{\circ} \mathrm{C}$ until species identification and DNA extraction. Ticks were identified to species and life stage by trained and experienced technicians who used various taxonomic keys [42-45].

\section{DNA extraction, qPCR assays and sequencing procedures}

DNA was extracted from ticks using a Qiagen DNA extraction procedure. For the detection of B. burgdorferi (s.l.), a duplex qPCR was used, based on the detection of fragments of ospA and flagellin genes [5]. A conventional PCR assay, targeting the 5S-23S intergenic region (IGS), was performed for B. burgdorferi (s.l.) species identification [46]. Conventional PCR assays were carried out in a Px2 thermal cycler (Thermo Electron Corporation, Breda, the Netherlands) and visualized on a $2 \%$ agarose gel. Both strands of PCR products were sequenced by BaseClear (Leiden, the Netherlands), according to the company's protocol and using the same forward and reverse primers as in conventional PCR. BLAST analyses and in-house molecular epidemiological databases (Bionumerics 7.1. - Applied Math, Belgium) were used to identify Borrelia burgdorferi (s.l.) species. These databases contain all our DNA sequences from (field) isolates, together with (reference) sequences from GenBank [47, 48].

For detection of $B$. miyamotoi, a qPCR assay was used that targets a region of the flagellin gene, specific for $B$. miyamotoi [49]. For detection of $A$. phagocytophilum and ' $C a$. N. mikurensis' DNA, a single duplex qPCR assay was used, which is described elsewhere [50, 51]. This qPCR assay targets specific regions of genes $m s p 2$ (major surface protein 2) for A. phagocytophilum and groEL (heat shock protein) for ' $\mathrm{Ca}$. N. mikurensis'. For detection of $R$. helvetica, we used a multiplex qPCR assay, targeting the gltA gene, as described earlier [52].

All qPCR runs were carried out in a final volume of $20 \mu \mathrm{l}$, containing IQ Multiplex Powermix (Bio-Rad, Hercules, CA, USA), $400 \mathrm{nM}$ of primers and hydrolysis probes and $3 \mu \mathrm{l}$ of DNA template. Conditions for PCR amplification were the following: $95{ }^{\circ} \mathrm{C}$ for $5 \mathrm{~min}, 60 \mathrm{cy}$ cles at $95{ }^{\circ} \mathrm{C}$ for $5 \mathrm{~s}$ and $60{ }^{\circ} \mathrm{C}$ for $35 \mathrm{~s}$, followed by a final incubation step at $37^{\circ} \mathrm{C}$ for $20 \mathrm{~s}$. qPCR assays were carried out on a LightCycler 480 instrument (Roche Diagnostics Nederland B.V, Almere, the Netherlands) and analysis was performed by the instrument's software (release 1.5.1.62). Quantification cycle $\left(\mathrm{C}_{\mathrm{q}}\right)$ values were calculated using the second derivative method. 


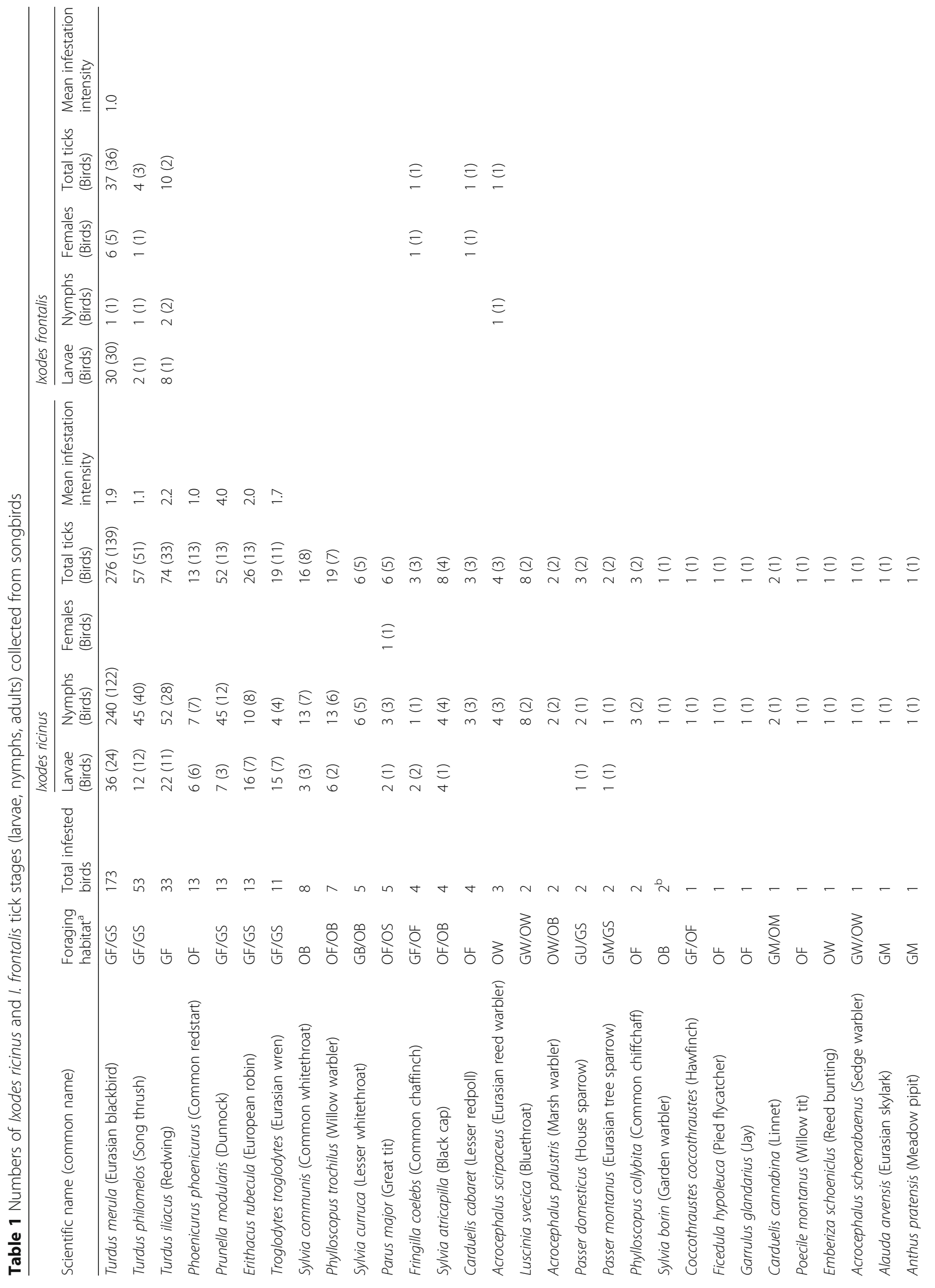




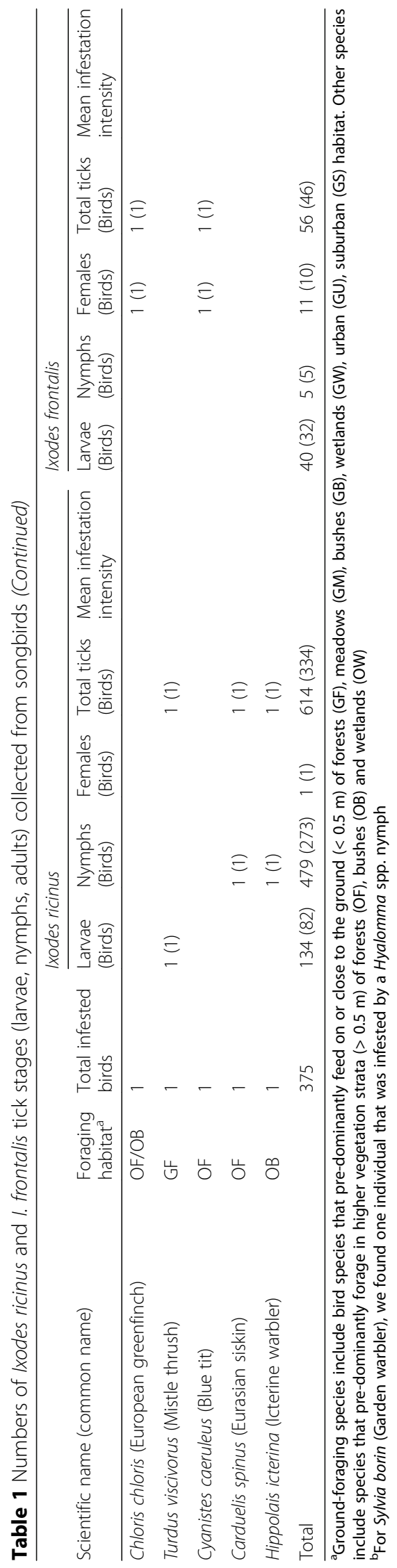




\section{Statistical analysis}

Generalized linear mixed effects models (GLMM) were fitted to test whether co-occurrences of different pathogen species in individual ticks were independent of each other (logit-link, binomial-distributed residuals), taking into account the correlation structure of cofeeding ticks that were obtained from the same individual [53]. In these models, individual birds were nested within bird species; both were modelled as random effects. For the inference of the maximum likelihood estimates of the fixed effects, Kenward Roger approximation was used to estimate the denominator degrees of freedom of the F-distributed test statistics, which takes into account the correlation of observations within the same cluster $[53,54]$. For those bird species of which at least 10 individuals were caught, mean tick infestation intensity (i.e. the average number of ticks in infested individuals) was calculated. For bird species with at least 10 infected individuals per tick stage, estimates of proportions of infected ticks are given by their arithmetic mean \pm standard error (i.e. the square root of the estimated variance/ the square root of the number of bird individuals) in the main text. Data management and statistical analyses were performed using SAS v9.2 (SAS Institute, Cary, North Carolina, USA).

\section{Results}

\section{Tick infestations}

Overall, 375 infested individual birds were trapped, belonging to 35 different species that could be classified into nine categories based on foraging habitats (Table 1). Thrushes (Turdus merula: 173, T. philomelos: 53, T. iliacus: 33 ) were trapped most often, representing $69 \%$ of the total number of infected birds. A total of 671 ticks was collected from the birds, belonging to three species: Ixodes ricinus (134 larvae, 479 nymphs and 1 adult female; collected from 334 birds), I. frontalis (40 larvae, 5 nymphs and 11 adult females; collected from 46 birds) and one Hyalomma spp. nymph from Sylvia borin (Table 1). Six individual birds (2 T. merula, 2 T. iliacus, $1 \mathrm{~T}$. philomelos and 1 Acrocephalus scirpaceus) were infected with both $I$. ricinus and $I$. frontalis.

For $I$. ricinus, tick infestation intensity was highest for Prunella modularis $(4.0 \pm 1.5 ; n=13)$, followed by $T$. iliacus $(2.2 \pm 0.4 ; n=33)$, Erithacus rubecula (2.0 $\pm 0.6 ; n=$ $13)$ and $T$. merula $(1.9 \pm 0.2 ; n=139)$. For I. frontalis, the infestation intensity for T. merula was $1.0 \pm 0.0(n=36)$.

\section{Pathogens in bird-derived ticks}

All 671 ticks were individually screened for the presence of B. burgdorferi (s.l.), B. miyamotoi, A. phagocytophilum, ' $C a$. N. mikurensis' and $R$. helvetica (Table 2). Overall, $50.9 \%(341 / 670)$ of ixodid ticks collected were found infected with one or more of these pathogens [I. ricinus:
$54 \%$ (333/614), I. frontalis 14\% (8/56)]. We found none of these pathogens in the one Hyalomma spp. nymph.

We detected B. burgdorferi (s.l.) DNA in 33.9\% (227/ $670)$ of all ixodid ticks. The highest proportion of $B$. burgdorferi (s.l.) positive larvae was observed in T. philomelos (91.6 $\pm 0.8 \% ; n=12$ infested birds), followed by $T$. merula (30.5 $\pm 9.2 \% ; n=24$ birds) and T. iliacus (9.09 \pm $9.09 \% ; n=11$ birds). The proportions of positive $I$. ricinus were higher in nymphs than in larvae when collected from $T$. merula (53.6 $\pm 4.2 \% ; n=122$ birds) and $T$. iliacus $(25.4 \pm 8.3 \%$; $n=28$ birds) but not from $T$. philomelos $(61.7 \pm 7.7 \% ; n=40$ birds). From latter members of the Turdidae family, we mainly found avian species ( $B$. garinii, B. valaisiana and B. turdi) in both larvae and nymphs (Table 3 ). In Prunella modularis (mean prevalence: $20.2 \pm 8.5 \% ; \quad n=12$ infested birds) only the mammal-associated $B$. afzelii (8 infected nymphs belonging to 5 infested birds) was found. Overall, for the complete set of Borrelia-infected ticks for which the Borrelia-genotyping was successful (173 tick individuals belonging to 15 bird species), avian species were detected in all developmental stages, while B. afzelii was detected in nymphs only (Table 3). Borrelia turdi was found in I. frontalis (2 adult females) and I. ricinus (3 nymphs).

The occurrence of B. miyamotoi in ticks was very low [prevalence in ixodid ticks: $0.6 \%$ (4/670)]. It was only found in one I. ricinus larva from E. rubecula and one $I$. ricinus nymphs from $T$. merula, Phylloscopus collybita, T. philomelos each.

For A. phagocytophilum, we detected DNA in $5.1 \%$ $(34 / 670)$ of all ixodid ticks. The nymphal infection prevalence in the four bird species with more than 10 infested birds varied between $1.4 \pm 0.9 \%$ ( $P$. modularis) and $8 \pm 4.9 \%$ (T. iliacus). Furthermore, A. phagocytophilum DNA was found in two I. frontalis females from one individual blackbird as well.

The overall prevalence of ' $\mathrm{Ca}$. N. mikurensis' in the ixodid ticks was $4.4 \%(30 / 670)$. A high prevalence was found in $I$. ricinus nymphs collected from $T$. philomelos (22.5 $\pm 6.7 \% ; n=40$ infested birds), but below $5.5 \%$ in the other Turdidae. Only two larvae, I. ricinus collected from Troglodytes troglodytes and $T$. iliacus, carried ' $C a$. N. mikurensis' DNA.

Compared to the other rickettsial infections, the number of ticks with $R$. helvetica - DNA was high [overall prevalence: $21.6 \%$ (145/670); Table 2]. Infection prevalence ranged from $10.7 \pm 5.4 \%$ ( $T$. iliacus; $n=28$ infested birds) to $29.2 \pm 7.2 \%$ (T. philomelos; $n=40$ infested birds) in those bird species with at least 10 nymphs. But also in the bird species of which we obtained a smaller amount of information (i.e. less than 10 infested birds) high prevalence was registered (e.g. nymphs in E. rubecula: $41.7 \pm 17.5 \%$; $n=8$; Sylvia communis: $42.9 \pm 20.2 \%$; 


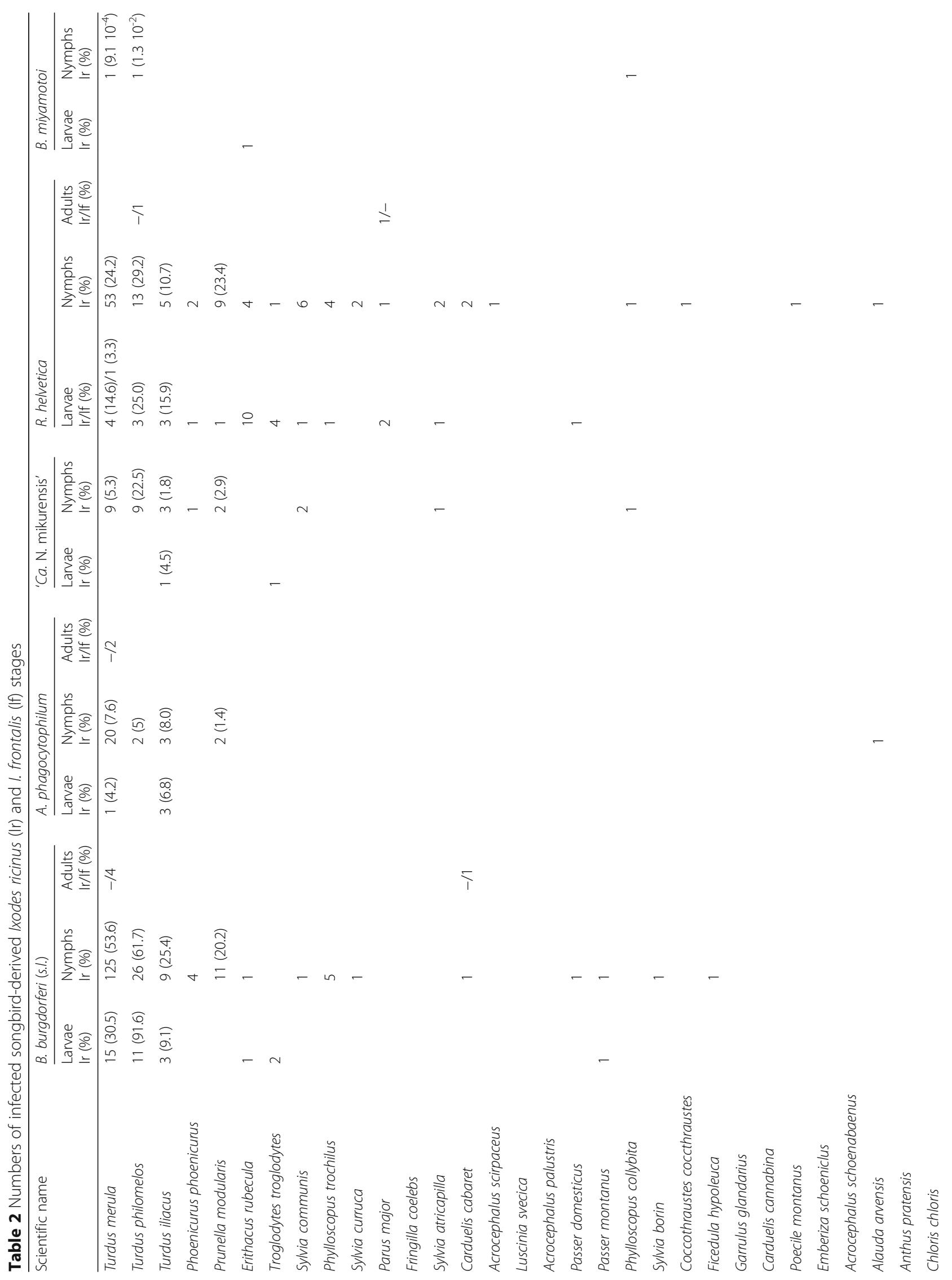




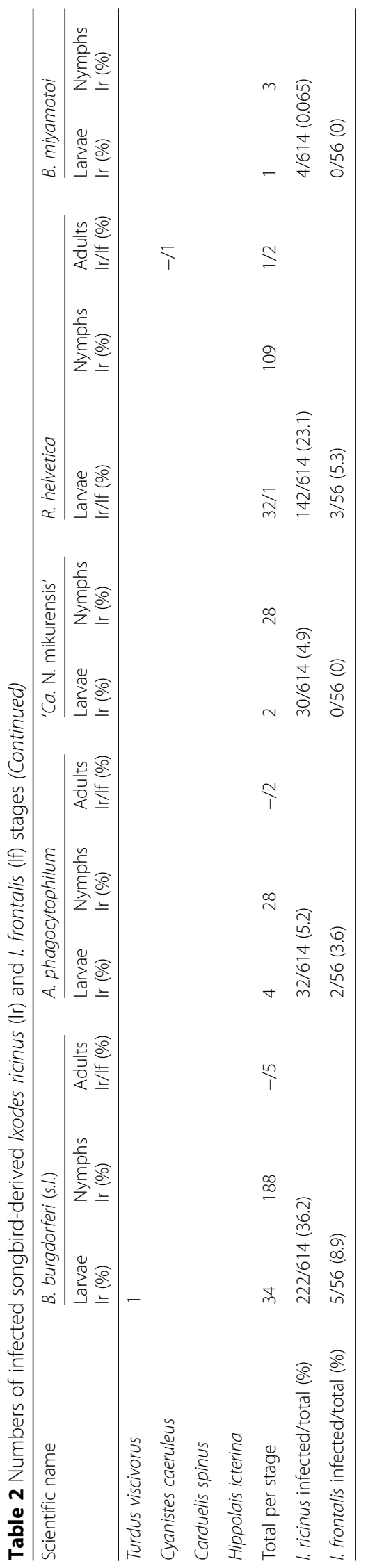


Table 3 Borrelia burgdorferi (s.l.) species in Ixodes ricinus and I. frontalis collected from 110 bird individuals

\begin{tabular}{|c|c|c|c|c|c|c|c|c|c|c|c|}
\hline \multirow[t]{2}{*}{ Scientific name } & \multicolumn{3}{|c|}{ B. garinii } & \multicolumn{2}{|c|}{ B. valaisiana } & \multicolumn{2}{|c|}{ B. afzelii } & \multicolumn{3}{|l|}{ B. turdi } & \multirow{2}{*}{$\begin{array}{l}\text { Total infestec } \\
\text { birds }\end{array}$} \\
\hline & $\begin{array}{l}\text { Larvae } \\
\text { Ir }\end{array}$ & $\begin{array}{l}\text { Nymphs } \\
\text { Ir }\end{array}$ & $\begin{array}{l}\text { Adults } \\
\text { If }\end{array}$ & $\begin{array}{l}\text { Larvae } \\
\text { Ir }\end{array}$ & $\begin{array}{l}\text { Nymphs } \\
\text { Ir }\end{array}$ & $\begin{array}{l}\text { Larvae } \\
\text { Ir }\end{array}$ & $\begin{array}{l}\text { Nymphs } \\
\text { Ir }\end{array}$ & $\begin{array}{l}\text { Larvae } \\
\text { Ir }\end{array}$ & $\begin{array}{l}\text { Nymphs } \\
\text { Ir }\end{array}$ & $\begin{array}{l}\text { Adults } \\
\text { If }\end{array}$ & \\
\hline Turdus merula & 5 & 47 & 1 & 5 & 44 & & 4 & & 2 & 1 & 64 \\
\hline Turdus philomelos & 2 & 7 & & 1 & 4 & & 5 & & 1 & & 20 \\
\hline Prunella modularis & & & & & & & 8 & & & & 5 \\
\hline Turdus iliacus & 3 & 5 & & & & & 1 & & & & 5 \\
\hline Phoenicurus phoenicurus & & 2 & & & & & 1 & & & & 3 \\
\hline Phylloscopus trochilus & & & & & & & 3 & & & & 2 \\
\hline Troglodytes troglodytes & 2 & & & & & & & & & & 2 \\
\hline Carduelis cabaret & & & & & & & 1 & & & 1 & 2 \\
\hline Ficedula hypoleuca & & 1 & & & & & & & & & 1 \\
\hline Sylvia curruca & & & & & & & 1 & & & & 1 \\
\hline Sylvia communis & & & & & & & 1 & & & & 1 \\
\hline Passer domesticus & & 1 & & & & & & & & & 1 \\
\hline Passer montanus & & & & 1 & & & & & & & 1 \\
\hline Erithacus rubecula & & & & & & & 1 & & & & 1 \\
\hline Turdus viscivorus & 1 & & & & & & & & & & 1 \\
\hline Total per stage & 13 & 63 & 1 & 7 & 48 & & 26 & & 3 & 2 & \\
\hline Infected/total (\%) & \multicolumn{3}{|c|}{$77 / 163(47.2)$} & \multicolumn{2}{|c|}{$55 / 163(33.7)$} & $26 / 163$ & 5.9) & \multicolumn{3}{|c|}{$5 / 163(3.1)$} & \\
\hline
\end{tabular}

$n=7 ;$ Phoenicurus phoenicurus: $28.6 \pm 18.4 \%$; $n=7$ ). Rickettsia helvetica-positive I. ricinus larvae were collected from 12 different songbird species. In general, larval prevalence was lower, but still high (range in Turdidae: $14.6 \pm 7.0 \%-25.0 \pm 13.1 \%)$. In addition, this bacterium was detected in an I. frontalis larva collected from $T$. merula and two I. frontalis adult females from C. caeruleus and T. philomelos.

\section{Co-infection}

Over $10 \%(13.4 \%, 90 / 671)$ of bird-derived ticks contained DNA of more than one pathogenic agent. At the bird level, $19.7 \%$ of individual birds (74/375) carried ticks with a co-infection. In I. ricinus larvae and nymphs, the most common pathogen combinations were ' $B$. burgdorferi (s.l.) $+R$. helvetica' (larvae: 6 ticks; nymphs: 46 ticks over 44 birds), followed by 'B. burgdorferi (s.l.) + 'Ca. N. mikurensis' (larvae: 0 ticks; nymphs: 17 ticks over 17 birds) and 'B. burgdorferi (s.l.) + A. phagocytophilum' (larvae: 0 ticks; nymphs: 17 ticks over 11 birds).

There was no statistical evidence for an association between B. burgdorferi (s.l.) and R. helvetica neither in $I$. ricinus nymphs $\left(F_{(1,204)}=0.35, P=0.55\right)$ nor $I$. ricinus larvae $\left(F_{(1,21)}=0.04, P=0.83\right)$ when taking host species and bird individual into account as a random effects. The same holds for B. burgdorferi (s.l.) and A. phagocytophilum (nymphs: $F_{(1,205)}=3.00, P=0.09$; larvae: no model convergence). We did find a positive correlation between the occurrence of ' $C a$. N. mikurensis' and $B$. burgdorferi (s.l.) (nymphs: logit absence-presence $=-1.02 \pm$ $0.46, F_{(1,205)}=4.9, P=0.028$; larvae: no model convergence). The analysis on the level of individual birds in which for each bird a binary value ("1": at least one infected tick, or "0": no infected ticks) was assigned as response variable did not change the conclusions (no significant association between B. burgdorferi (s.l.) and A. phagocytophilum, nor B. burgdorferi (s.l.) and R. helvetica: all $P$-values $>0.33)$. The same holds for the association between ' $\mathrm{C} a$. N. mikurensis' and B. burgdorferi (s.l.) (logit absence-presence $=-1.48 \pm 0.49, F_{(1,300)}=8.99, P=$ 0.003). Due to low sample sizes, associations between other pathogen combinations could not be analyzed.

The following rare combinations of pathogens in ticks were found: $R$. helvetica + 'Ca. N. mikurensis' (larvae: 1 tick; nymphs: 9 ticks over 9 birds); A. phagocytophilum $+R$. helvetica (larvae: 1 tick; nymphs: 7 ticks over 6 birds); B. burgdorferi (s.l.) + B. miyamotoi (1 nymph); $B$. miyamotoi + 'Ca. N. mikurensis' (1 nymph). Six nymphs (over 6 birds) carried DNA of B. burgdorferi (s.l.), R. helvetica and ' $C a$. N. mikurensis' and three nymphs were infected with the combination B. burgdorferi (s.l.) $+R$. helvetica $+A$. phagocytophilum (over 2 birds). Also in the smaller set of $I$. frontalis ticks, we found the coinfection B. burgdorferi (s.l.) + A. phagocytophilum in two adult females collected from a single $T$. merula. 


\section{Discussion}

We have shown that half of the songbird-derived I. ricinus ticks, that readily feed on humans, contained DNA of one or more bacteria that are pathogenic to humans: B. burgdorferi (s.l.), R. helvetica, A. phagocytophylum, B. miyamotoi, 'Ca. N. mikurensis'. The presence of the DNA in the ticks shows that songbirds carry infected ticks and may facilitate bacterium transmission. Transmission facilitation via birds may occur either via the infection of bird tissue on which ticks feed or via cofeeding of ticks in close spatial and temporal proximity to each other. The latter transmission pathway can occur in the absence of a systemic infection, allowing some pathogens (e.g. Borrelia species) to evade the hostile immune system of otherwise incompetent hosts [55].

Ground-dwelling birds, especially the members of the family Turdidae, had the highest infestation intensities and also yielded the highest numbers of infected ticks overall. They are known to run a greater risk of I. ricinus exposures, as they forage inside the habitat of this abundant tick species (i.e. ground and lower vegetation strata) $[4,56]$. Particularly the blackbird (T. merula) and the song thrush (T. philomelos), two very common birds of European woodlands and gardens, contributed strongly to the number of infected ticks. In line with other European studies, birds were predominantly infested by immature $I$. ricinus stages and rarely by adult females. Adult $I$. ricinus are typically found on mediumsized and larger mammals (e.g. roe deer) on which they copulate [57]. In contrast but not surprising, we found substantial numbers of semi-engorged adult female $I$. frontalis on the birds; all developmental stages $I$. frontalis feed on birds [42].

We found a strong association of $B$. garinii, $B$. valaisiana and $B$. turdi with avian reservoir hosts, which has previously been shown by numerous European field studies concluding that birds act both as competent reservoirs and transmitters for these species [10-12, 29, 58-60]. Given that vertical transmission of B. burgdorferi (s.l.) spirochetes in I. ricinus ticks only rarely occurs $[61,62]$, their presence in larvae (Tables 2, 3 ) indicates that they were acquired either via (local) infection in the host or via co-feeding with an infected nymph. Borrelia turdi, recently discovered in Europe and strongly associated with $I$. frontalis, was also found in $I$. ricinus nymphs. Transmission experiments have shown that $I$. ricinus can transmit $B$. turdi to naïve avian hosts and, seen the extreme host range of this tick species, $I$. ricinus could potentially act as a bridging vector towards mammals, including human [60]. Recent experimental and observational studies based on larval and nymphal infections show non-homogeneous distributions of the avian Borrelia species in bird-derived ticks, indicating differential transmission and amplification of these species depending on the avian reservoir hosts and tick species [12, 60, 63].

An interesting outcome of our study and previous field studies is that several of the ground-dwelling birds (T. merula, T. philomelos, E. rubecula and P. modularis) were frequently infested with ticks that carried $B$. afzelii, a species that is associated with rodent reservoir hosts $[64,65]$. The fact that all B. afzelii-infected ticks were nymphs suggests that these individuals had fed as a larva on a $B$. afzelii-infected mammal, moulted and maintained their infections when feeding on the birds. Findings of bird-derived infected larvae in other studies have led to speculations that particular strains of $B$. afzelii can also use bird hosts for transmission [14]. PCR-based screening outcomes, like ours and others, should, however, be interpreted with caution as they are based on the detection of specific DNA sequences and do not necessarily mean that viable, infectious microorganisms are present. A recent experimental study investigating transmission of $B$. afzelii in blackbirds and great tits showed that nymph-to-adult transstadial transmission of B. afzelii DNA could occur. However, the positive signal in the adult ticks turned out not to be viable and infectious spirochetes, as shown by the BSK culture test [66]. It is, therefore, necessary to identify the $B$. afzelii strains found in bird-derived ticks from the wild and test via culture-based infection methods and tick transmission experiments whether they are still infectious and transmittable after being exposed to bird blood during tick feeding.

Also for the more sporadically observed mammalassociated pathogens ( $B$. miyamotoi and ' $C a$. N. mikurensis') that we detected in bird-derived ticks, including larvae (Table 2), experiments are needed to investigate whether viable bacteria survive the birds immune system and/or are transmitted during tick feeding. Studies in the USA and Europe have implicated small rodent species as the reservoir hosts for B. miyamotoi [34, 67], but a limited number of studies reported B. miyamotoi infections from bird-derived ticks as well $[17,29,68]$. For the rodent-associated 'Ca. N. mikurensis' [50] observed in bird-derived $I$. ricinus larvae and nymphs of our study and others [28, 29], a role for songbirds as transmission facilitators could be expected.

Compared to the other A. phagocytophilum and ' $\mathrm{Ca}$. $\mathrm{N}$. mikurensis', the number of ticks with $R$. helvetica DNA was high. A good comprehension of the transmission dynamics of rickettsial bacteria in songbirds is still lacking. Within infected ticks, a proportion of the bacteria could have a maternal origin, as $R$. helvetica, in contrast to Borrelia burgdorferi (s.l.), can be transmitted transovarially $[69,70]$. However, the experimental study of Heylen et al. [17] using great tits (Parus major) exposed to a community of pathogens, clearly shows rapid 
$R$. helvetica transmission via co-feeding (cf. mammals $[71,72]$ ) and/or fast systemic infection (as found in mammals experimentally injected with different rickettsial species [73]). Our and other's finding of $R$. helvetica in bird-derived ticks, including larvae [3, 29-31, 51, 74, 75] reinforces the presumption that songbirds can become bacteraemic and effectively facilitate the transmission of this pathogen via host tissue [30].

Further, our study provides evidence that grounddwelling birds, especially thrushes, are important hosts in the transmission cycles of A. phagocytophilum. Bacteraemia of this pathogen has been shown to develop in songbirds [30], which is likely the reason for the reports of infected bird-derived ticks here and other locations $[25,26,29,30,76]$. Probably not all birds are equally competent in the transmission; in a great tit (Parus major) experiment by Heylen et al. [17] no transmission facilitation occurred despite the presence of $A$. phagocytophilum in challenge nymphs. Our finding of infections in a bird-specialized tick (I. frontalis) that is never found on other vertebrate hosts (two infected adult females cofeeding with infected I. ricinus nymphs on the same blackbird individuals) gives further indication that birds facilitate A. phagocytophilum transmission, either via cofeeding transmission or systemic infections. Although the host-specific strains of A. phagocytophilum were not identified, the avian ecotype IV that has been isolated by Jahfari et al. [51] from blackbird tissues and blackbirdderived ticks is to be expected.

The co-infections found in individual ticks and birds strongly suggest that simultaneous transmission of different bacterium species can occur and that birds are permissive for multiple pathogens, as experimentally shown in Heylen et al. [28]. Especially, the fact that coinfections were found in (sets of) larvae provides the strongest indication. However, larvae could also acquire pathogens via the maternal line from other hosts than the individual songbird from which they were collected, through vertical transmission (e.g. in B. miyomatoi and $R$. helvetica) [69, 70, 77]. In larvae, the most frequent observed co-infection was B. burgdorferi (s.l.) with $R$. helvetica (E. rubecula, T. troglodytes, T. philomelos), but also A. phagocytophilum with $R$. helvetica and 'Ca. N. mikurensis' with $R$. helvetica (both from $T$. iliacus) were observed. Only for one bacterial combination, ' $C a$. $\mathrm{N}$. mikurensis' + B. burgdorferi (s.l.), we found that the occurrence of the one pathogen is more likely when another pathogenic agent is present. Interestingly, also in mammals, this combination of pathogens was much higher than expected from the prevalence of each pathogen [39]. This positive association could be the result of variation in general susceptibility among birds, but could also indicate transmission facilitation, as has been suggested in other studies on tick-borne co- infections [18, 34, 78]. The pathways that lead to facilitation can only be elucidated with experimental studies in which pathogen-driven physiological, cellular and biochemical interactions are disentangled.

\section{Conclusions}

Our findings highlight the contribution of songbirds to co-infections in individual ticks. In addition, not only avian but also mammalian bacterium species are transported via bird-derived ticks, highlighting the need to experimentally test whether latter pathogens are viable and infectious in birds. Furthermore, future studies should focus on the reservoir competence of members in the bird community and how the different vector-bird-niches contribute to the pathogen transmission dynamics.

\section{Acknowledgements \\ We would like to thank Marieta Braks (RIVM) for critically proofreading the manuscript and Joris Elst (University of Antwerp) for sharing his expert knowledge on the foraging habits and habitats of local songbirds.}

\section{Funding}

This study was financially supported by the Dutch Ministry of Health, Welfare and Sport (WWS), the Fund for Scientific Research - Flanders Belgium (FWO) (grant G0.049.10) and the University of Antwerp (KP BOF UA 2015). This work was done under the frame of EurNegVec Cost Action TD1303. Dieter Heylen is a postdoctoral fellow at the Fund for Scientific Research - Flanders Belgium (FWO). The funders had no role in study design, data collection, interpretation and analysis, decision to publish or preparation of the manuscript.

\section{Availability of data and materials}

The datasets used and/or analyzed during the current study are available from the corresponding author on reasonable request. Representative sequences were submitted to the GenBank database with the accession numbers LC325576-LC325737.

\section{Authors' contributions}

$\mathrm{DH}$ and $\mathrm{AdB}$ analysed data and wrote the final manuscript. $\mathrm{DH}$ collected tick from trapped birds in Belgium and AS, SW and MD from birds in the Netherlands. $\mathrm{DH}, \mathrm{SW}$ and MF performed identifications of tick species and tick stages. ADVL, MF and SJ performed and analysed laboratory tests. HS organized and supervised the study. All authors read and approved the final manuscript.

Ethics approval and consent to participate

The study was carried out according to the national animal welfare regulations.

Consent for publication

Not applicable.

\section{Competing interests}

The authors declare that they have no competing interests.

\section{Publisher's Note}

Springer Nature remains neutral with regard to jurisdictional claims in published maps and institutional affiliations.

\section{Author details}

${ }^{1}$ Evolutionary Ecology Group, University of Antwerp, Antwerp, Belgium. ${ }^{2}$ Centre for Zoonoses \& Environmental Microbiology, Centre for Infectious Disease Control, National Institute for Public Health and the Environment, Bilthoven, The Netherlands. ${ }^{3}$ Centre for Monitoring of Vectors, Netherlands Food and Consumer Product Safety Authority, Ministry of Economic Affairs, Wageningen, The Netherlands. ${ }^{4}$ Independent agricultural entrepreneur, Groningen, The Netherlands. ${ }^{5}$ Resource Ecology Group, Wageningen University, Wageningen, The Netherlands. ${ }^{6}$ EcoEpidemiology Lab, Columbia University, New York, USA. 
Received: 19 May 2017 Accepted: 4 October 2017

Published online: 18 October 2017

\section{References}

1. Bjöersdorff A, Bergström S, Massung RF, Haemig PD, Olsen B. Ehrlichiainfected ticks on migrating birds. Emerg Infect Dis. 2001;7:877-9.

2. Waldenström J, Lundkvist A, Falk Kl, Garpmo U, Bergstrom S, Lindegren G, et al. Migrating birds and tickborne encephalitis virus. Emerg Infect Dis. 2007;13:1215-8.

3. Elfving K, Olsen B, Bergstrom S, Waldenstrom J, Lundkvist A, Sjostedt A, et al. Dissemination of spotted fever Rickettsia agents in Europe by migrating birds. PLoS One. 2010;5(1):e8572.

4. Comstedt P, Bergstrom S, Olsen B, Garpmo U, Marjavaara L, Mejlon H, et al. Migratory passerine birds as reservoirs of Lyme borreliosis in Europe. Emerg Infect Dis. 2006;12:1087-95.

5. Heylen D, Tijsse E, Fonville M, Matthysen E, Sprong H. Transmission dynamics of Borrelia burgdorferi s.l. in a bird tick community. Environ Microbiol. 2013;15:663-73.

6. Ulmanen I, Saikku P, Vikberg P, Sorjonen J. Ixodes lividus (Acari) in sand martin colonies in Fennoscandia. Oikos. 1977;28:20-6.

7. Hudde H, Walter G. Verbreitung und Wirtswahl der Vogelzecke Ixodes arboricola (Ixodoidea, Ixodidae) in der Bundesrepublik Deutschland. Vogelwarte. 1988;34:201-7.

8. Lundqvist L, Gray JS, Hillyard PD. Ixodes frontalis on the Baltic island of Gotland. Sweden Med Vet Entomol. 1998;12:215-6.

9. Hofmeester TR, Coipan EC, van Wieren SE, Prins HHT, Takken W, Sprong H. Few vertebrate species dominate the Borrelia burgdorferi s.l. life cycle. Environ Res Lett. 2016;11(4):043001.

10. Humair PF, Postic D, Wallich R, Gern L. An avian reservoir (Turdus merula) of the Lyme borreliosis spirochetes. Int J Med Microbiol Virol Parasitol Infect Dis. 1998;287:521-38

11. Taragel'ova V, Koci J, Hanincova K, Kurtenbach K, Derdakova M, Ogden NH, et al. Blackbirds and song thrushes constitute a key reservoir of Borrelia garinii, the causative agent of borreliosis in Central Europe. Appl Environ Microbiol. 2008;74:1289-93.

12. Heylen D, Matthysen E, Fonville M, Sprong H. Songbirds as general transmitters but selective amplifiers of Borrelia burgdorferi sensu lato genotypes in Ixodes rinicus ticks. Environ Microbiol. 2014;16:2859-68.

13. Dubska L, Literak I, Kocianova E, Taragelova V, Sverakova V, Sychra O, et al. Synanthropic birds influence the distribution of Borrelia species: analysis of Ixodes ricinus ticks feeding on passerine birds. Appl Environ Microbiol. 2011;77:1115-7

14. Franke J, Moldenhauer A, Hildebrandt A, Dorn W. Are birds reservoir hosts for Borrelia afzelii? Ticks Tick-Borne Dis. 2010;1:109-12.

15. Stanek G, Reiter M. The expanding Lyme Borrelia complex-clinical significance of genomic species? Clin Microbiol Infect. 2011;17:487-93.

16. Strle F, Stanek G. Clinical manifestations and diagnosis of lyme borreliosis. Curr Probl Dermatol. 2009;37:51-110.

17. Heylen D, Fonville M. Docters van Leeuwen A. Sprong H. Co-infections and transmission dynamics in a tick-borne bacterium community exposed to songbirds Environl Microbiol. 2016;18:988-96.

18. Ginsberg HS. Potential effects of mixed infections in ticks on transmission dynamics of pathogens: comparative analysis of published records. Exp Appl Acarol. 2008:46:29-41.

19. Thomas V, Anguita J, Barthold SW, Fikrig E. Coinfection with Borrelia burgdorferi and the agent of human granulocytic ehrlichiosis alters murine immune responses, pathogen burden, and severity of Lyme arthritis. Infect Immun. 2001;69:3359-71.

20. Moro MH, Zegarra-Moro OL, Bjornsson J, Hofmeister EK, Bruinsma E, Germer $\mathrm{J}$, et al. Increased arthritis severity in mice coinfected with Borrelia burgdorferi and Babesia microti. J Infect Dis. 2002;186:428-31.

21. Duncan $A B$, Agnew $P$, Noel $V$, Michalakis $Y$. The consequences of $\mathrm{CO}$ infections for parasite transmission in the mosquito Aedes aegypti. J Anim Ecol. 2015;84:498-508.

22. Susi H, Barres B, Vale PF, Laine AL. Co-infection alters population dynamics of infectious disease. Nature Comm. 2015;6:5975

23. Holden K, Hodzic E, Feng S, Freet KJ, Lefebvre RB, Barthold SW. Coinfection with Anaplasma phagocytophilum alters Borrelia burgdorferi population distribution in C3H/HeN mice. Infect Immun. 2005:73:3440-4.

24. Hildebrandt A, Franke J, Meier F, Sachse S, Dorn W, Straube E. The potential role of migratory birds in transmission cycles of Babesia spp., Anaplasma phagocytophilum, and Rickettsia spp. Ticks Tick-Borne Dis. 2010;1:105-7.
25. Palomar AM, Portillo A, Santibanez P, Mazuelas D, Roncero L, Garcia-Alvarez L, et al. Detection of tick-borne Anaplasma bovis, Anaplasma phagocytophilum and Anaplasma centrale in Spain. Med Vet Entomol. 2015;29:349-53.

26. Geller J, Nazarova L, Katargina O, Leivits A, Jarvekulg L, Golovljova I. Tickborne pathogens in ticks feeding on migratory passerines in western part of Estonia. Vector-Borne Zoonotic Dis. 2013;13:443-8.

27. Spitalska E, Literak I, Kocianova E, Taragel'ova V. The importance of Ixodes arboricola in transmission of Rickettsia spp., Anaplasma phagocytophilum, and Borrelia burgdorferi sensu lato in the Czech Republic, Central Europe. Vector-Borne Zoonotic Dis. 2011;11:1235-41.

28. Labbe Sandelin L, Tolf C, Larsson S, Wilhelmsson P, Salaneck E, Jaenson TG, et al. Candidatus Neoehrlichia mikurensis in ticks from migrating birds in Sweden. PLoS One. 2015;10(7):e0133250.

29. Lommano E, Dvorak C, Vallotton L, Jenni L, Gern L. Tick-borne pathogens in ticks collected from breeding and migratory birds in Switzerland. Ticks TickBorne Dis. 2014;5:871-82.

30. Hornok S, Kovats D, Csorgo T, Meli ML, Gonczi E, Hadnagy Z, et al. Birds as potential reservoirs of tick-borne pathogens: first evidence of bacteraemia with Rickettsia helvetica. Parasit Vectors. 2014;7:128.

31. Graham Rl, Mainwaring MC, Du Feu R. Detection of spotted fever group Rickettsia spp. from bird ticks in the UK. Med Vet Entomol. 2010:24:340-3.

32. Lipsker D, Jaulhac B. Lyme borreliosis: biological and clinical aspects. Basel, Switzerland: Karger; 2009

33. Humair PF, Gern L. The wild hidden face of Lyme borreliosis in Europe. Microbes Infect. 2000;2:915-22

34. Burri C, Schumann O, Schumann C, Gern L. Are Apodemus spp. mice and Myodes glareolus reservoirs for Borrelia miyamotoi, Candidatus Neoehrlichia mikurensis, Rickettsia helvetica, R. monacensis and Anaplasma phagocytophylum? Ticks Tick-Borne Dis. 2014;5:245-51.

35. Nilsson K, Lindquist O, Pahlson C. Association of Rickettsia helvetica with chronic perimyocarditis in sudden cardiac death. Lancet. 1999;354:1169-73.

36. Nilsson K, Elfving K, Pahlson C. Rickettsia helvetica in patient with meningitis, Sweden, 2006. Emerg Infect Dis. 2010;16:490-2.

37. Dumler JS, Choi KS, Garcia-Garcia JC, Barat NS, Scorpio DG, Garyu JW, et al. Human granulocytic anaplasmosis and Anaplasma phagocytophilum. Emerg Infect Dis. 2005;11:1828-34.

38. Maurer FP, Keller PM, Beuret C, Joha C, Achermann Y, Gubler J, et al. Close geographic association of human neoehrlichiosis and tick populations carrying "Candidatus Neoehrlichia mikurensis" in eastern Switzerland. J Clin Microbiol. 2013:51:169-76.

39. Andersson M, Scherman K, Raberg L. Infection dynamics of the tick-borne pathogen "Candidatus Neoehrlichia mikurensis" and coinfections with Borrelia afzelii in bank voles in southern Sweden. Appl Environ Microbiol. 2014:80:1645-9

40. Szekeres S, Coipan EC, Rigo K, Majoros G, Jahfari S, Sprong H, et al. Candidatus Neoehrlichia mikurensis and Anaplasma phagocytophilum in natural rodent and tick communities in southern Hungary. Ticks Tick-Borne Dis. 2015:6:111-6.

41. Snow D, Perrins CM, Gillmor R. The birds of the western Palearctic concise edition, vol. 2. Oxford: Oxford University Press; 1998.

42. Heylen D, De Coninck E, Jansen F, Madder M. Differential diagnosis of three common Ixodes spp. ticks infesting songbirds of Western Europe: Ixodes arboricola, I. frontalis and I. ricinus. Ticks Tick-Borne Dis. 2014;5:693-700.

43. Arthur DR. British ticks. London: Butterworths; 1963.

44. Hillyard PD. Ticks of North-West Europe. London: Backhuys Publishers; 1996.

45. Manila G. Acari, Ixodida. Edizioni Calderini: Bologna; 1998.

46. Coipan EC, Jahfari S, Fonville M, Maassen CB, van der Giessen J, Takken W, et al. Spatiotemporal dynamics of emerging pathogens in questing /xodes ricinus. Front Cell Infect Microbiol. 2013;3:36.

47. Coipan EC, Fonville M, Tijsse-Klasen E, van der Giessen JW, Takken W, Sprong $\mathrm{H}$, et al. Geodemographic analysis of Borrelia burgdorferi sensu lato using the 5S-23S rDNA spacer region. Infect Genet Evol. 2013:17:216-22

48. Coipan EC, Jahfari S, Fonville M, Oei GA, Spanjaard L, Takumi K, et al. Imbalanced presence of Borrelia burgdorferi s.I. multilocus sequence types in clinical manifestations of Lyme borreliosis. Infect Genet Evol. 2016;42:66-76.

49. Hovius JW, de Wever B, Sohne M, Brouwer MC, Coumou J, Wagemakers A et al. A case of meningoencephalitis by the relapsing fever spirochaete Borrelia miyamotoi in Europe. Lancet. 2013;382:658.

50. Jahfari S, Fonville M, Hengeveld P, Reusken C, Scholte EJ, Takken W, et al. Prevalence of Neoehrlichia mikurensis in ticks and rodents from north-west Europe. Parasit Vectors. 2012;5:74 
51. Jahfari S, Coipan EC, Fonville M, Van Leeuwen AD, Hengeveld P, Heylen D, et al. Circulation of four Anaplasma phagocytophilum ecotypes in Europe. Parasit Vectors. 2014;7:365.

52. de Bruin A, van Leeuwen AD, Jahfari S, Takken W, Foldvari M, Dremmel L, et al. Vertical transmission of Bartonella schoenbuchensis in Lipoptena cervi. Parasit Vectors. 2015:8:17.

53. Molenberghs $\mathrm{G}$, Verbeke $\mathrm{G}$. Models for discrete longitudinal data. BerlinHeidelberg-New York: Springer-Verlag; 2005.

54. Verbeke $\mathrm{G}$, Molenberghs $\mathrm{G}$. Linear mixed models for longitudinal data. Berlin-Heidelberg-New York: Springer-Verlag; 2001.

55. Voordouw MJ. Co-feeding transmission in Lyme disease pathogens. Parasitology. 2015;142:290-302.

56. Marsot M, Henry PY, Vourc'h G, Gasqui P, Ferquel E, Laignel J, et al. Which forest bird species are the main hosts of the tick, Ixodes ricinus, the vector of Borrelia burgdorferi sensu lato, during the breeding season? Int J Parasitol. 2012:42:781-8.

57. Gray JS. The ecology of ticks transmitting Lyme borreliosis. Exp Appl Acarol. 1998;22:249-58.

58. Hanincova K, Taragelova V, Koci J, Schafer SM, Hails R, Ullmann AJ, et al. Association of Borrelia garinii and B. valaisiana with songbirds in Slovakia. Appl Environ Microbiol. 2003;69:2825-30.

59. Kurtenbach K, Schafer SM, Sewell HS, Peacey M, Hoodless A, Nuttall PA, et al. Differential survival of Lyme borreliosis spirochetes in ticks that feed on birds. Infect Immun. 2002;70:5893-5.

60. Heylen D, Krawczyk Al, Lopes de Carvalho I, Sofia Núncio M, Sprong $H_{t}$ Norte AC. Bridging of cryptic Borrelia cycles in European songbirds. Environ Microbiol. 2017;19:1857-67.

61. Richter D, Debski A, Hubalek Z, Matuschka FR. Absence of Lyme disease spirochetes in larval Ixodes ricinus ticks. Vector-Borne Zoonotic Dis. 2012;12:21-7.

62. Rollend L, Fish D, Childs JE. Transovarial transmission of Borrelia spirochetes by Ixodes scapularis: a summary of the literature and recent observations. Ticks Tick-Borne Dis. 2013;4:46-51.

63. Heylen D. Ecological interactions between songbirds, ticks, and Borrelia burgdorferi s.l. in Europe, vol. 4. Wageningen: Wageningen Academic Publishers; 2016.

64. Hanincova K, Schafer SM, Etti S, Sewell HS, Taragelova V, Ziak D, et al. Association of Borrelia afzelii with rodents in Europe. Parasitology. 2003;126:11-20.

65. Humair PF, Rais O, Gern L. Transmission of Borrelia afzelii from Apodemus mice and Clethrionomys voles to Ixodes ricinus ticks: differential transmission pattern and overwintering maintenance. Parasitology. 1999;118:33-42.

66. Heylen D, Sprong H, Krawczyk Al, Van Houtte N, Genné D, GomezChamorro A, et al. Inefficient co-feeding transmission of Borrelia afzelii in two common European songbirds. Sci Rep. 2017;7

67. Scoles GA, Papero M, Beati L, Fish D. A relapsing fever group spirochete transmitted by Ixodes scapularis ticks. Vector-Borne Zoonotic Dis. 2001;1:21-34.

68. Hamer SA, Hickling GJ, Keith R, Sidge JL, Walker ED, Tsao Jl. Associations of passerine birds, rabbits, and ticks with Borrelia miyamotoi and Borrelia andersonii in Michigan, USA. Parasit Vectors. 2012;5:231

69. Sprong $\mathrm{H}$, Wielinga PR, Fonville $\mathrm{M}$, Reusken $\mathrm{C}$, Brandenburg $\mathrm{AH}$, Borgsteede $F$, et al. Ixodes ricinus ticks are reservoir hosts for Rickettsia helvetica and potentially carry flea-borne Rickettsia species. Parasit Vectors. 2009;2:41.

70. Parola P, Paddock CD, Raoult D. Tick-borne rickettsioses around the world: emerging diseases challenging old concepts. Clinical Microbiol Rev. 2005;18:719-56.

71. Kocan KA, de la Fuente J. Co-feeding studies of ticks infected with Anaplasma marginale. Vet Parasitol. 2003;112:295-305.

72. Zemtsova G, Killmaster LF, Mumcuoglu KY, Levin ML. Co-feeding as a route for transmission of Rickettsia conorii israelensis between Rhipicephalus sanguineus ticks. Exp Appl Acarol. 2010;52:383-92.

73. Beati L, Kelly PJ, Mason PR, Raoult D. Experimental infections of vervet monkeys (Cercopithecus pygerythrus) with three spotted fever group rickettsiae. South African J Sci. 1999:95:448-9.

74. Berthova L, Slobodnik V, Slobodnik R, Oleksak M, Sekeyova Z, Svitalkova Z, et al. The natural infection of birds and ticks feeding on birds with Rickettsia spp. and Coxiella burnetii in Slovakia. Exp Appl Acarol. 2015;68:299-314.

75. Wallmenius K, Barboutis C, Fransson T, Jaenson TG, Lindgren PE, Nystrom F, et al. Spotted fever Rickettsia species in Hyalomma and Ixodes ticks infesting migratory birds in the European Mediterranean area. Parasit Vectors. 2014;7:318.
76. Capligina V, Salmane I, Keiss O, Vilks K, Japina K, Baumanis V, et al. Prevalence of tick-borne pathogens in ticks collected from migratory birds in Latvia. Ticks Tick-Borne Dis. 2014;5:75-81.

77. Van Duijvendijk G, Coipan EC, Wagemakers A, Fonville M, Ersöz J, Oei A et al. Larvae of Ixodes ricinus transmit Borrelia afzelii and B. miyamotoi to vertebrate hosts. Parasit Vectors. 2016;9:1.

78. Dunn JM, Krause PJ, Davis S, Vannier EG, Fitzpatrick MG, Rollend L, et al. Borrelia burgdorferi promotes the establishment of Babesia microti in the northeastern United States. PLoS One. 2014;9(21):e115494.

\section{Submit your next manuscript to BioMed Central and we will help you at every step:}

- We accept pre-submission inquiries

- Our selector tool helps you to find the most relevant journal

- We provide round the clock customer support

- Convenient online submission

- Thorough peer review

- Inclusion in PubMed and all major indexing services

- Maximum visibility for your research

Submit your manuscript at www.biomedcentral.com/submit
C Biomed Central 